Arq. Bras. Med. Vet. Zootec., v.71, n.1, p.102-108, 2019

\title{
Clinical and pathological aspects of gossypiboma in a dog:case report
}

\author{
[Aspectos clínico-patológicos do gossipiboma em cão: relato de caso] \\ R. Oliveira, A. Matsui, J.O.Ribeiro*, G. Simionato, A.C. Simamura, \\ J. Canola, A. Camplesi, R.O. Vasconcelos, P. C. Moraes \\ Universidade Estadual Paulista "Júlio de Mesquita Filho"- UNESP - Campus II - Jaboticabal, SP
}

\begin{abstract}
A female dog was treated at the Veterinary Hospital Governador Laudo Natel for symptomscaused by an intra-abdominal gossypiboma (gossypium: cotton; boma: place of hiding). Showing high morbidity and mortality, the gossypiboma is a granulomatous reaction that is formed in response to exposure to a textile matrix. The objective of this report is to describe the clinical and pathological findings of an intraabdominal gossypiboma in a female dog. This patient arrived at urgent care showing increased abdominal volume, pain, and cachexia. Ultrasonography showed a regular contour formation that could not be completely delimited. The patient underwent exploratory laparotomy and died in the postoperative period. The gossypiboma had a smooth, firm, and purple-gray exterior surface. Microscopy revealed a severe reaction of desmoplasia around the necrotic region, residual textile material, and adipose tissue. Negligence by veterinarians leading to this condition can result in patients' death as well as causing psychological damage to owners.
\end{abstract}

Keywords:legal medicine, surgery, inflammatory reaction, textile

\section{RESUMO}

Uma cadela foi atendida no Hospital Veterinário "Governador Laudo Natel", apresentando sinais clínicos oriundos de gossipiboma intra-abdominal (gossypium: algodão e boma: local de ocultação), tais como aumento de volume abdominal, regurgitação e caquexia. A ultrassonografia evidenciou formação de contorno regular que não podia ser totalmente delimitada. A paciente foi submetida à laparotomia exploratória e veio a óbito no período pós-operatório. O gossipiboma mostrou-se com superfície externa lisa, firme e roxo-acinzentada apresentando-se à microscopia como reação severa de desmoplasia ao redor de material necrótico, resíduos de material têxtil e do tecido adiposo. A negligência por parte dos médicos veterinários pode levar pacientes ao óbito, bem como trazer prejuízos psicológicos aos proprietários. Objetiva-se, com este relato, descrever os achados clínicos e patológicos de uma cadela que apresentou um gossipiboma intra-abdominal.

Palavras-chave: medicina legal, cirurgia, reação inflamatória

\section{INTRODUCTION}

According to the Consumer Defense Code, the veterinarian is considered to be a service provider, while the owner of the animal is the consumer. Once this relationship is established, the veterinarian is subject to the duties and penalties existing in the consumer relationship (Malacarne, 2009). There are cases where the

Recebido em 24 de setembro de 2017

Aceito em 17 de setembro de 2018

*Autor para correspondência (corresponding author)

E-mail: juliana.oribeiro@yahoo.com.br veterinarian can be exempt from guilt due to unforeseen circumstances or those where the owner authorizes procedures where there is no avoidance of risk (Eko, 2011). However, legally, the veterinarian is obligated to be successful at elective sterilization surgery (Malacarne, 2009).

Some authors classify the ovariohysterectomy technique as simple, yet as with any surgical procedure, there are risks. The most common 
complications are bleeding, accidental ligation of the ureter, and granuloma formation because of the presence of surgical thread in the uterine stump (Santos et al., 2009). In medicine, it is relatively common to detect the presence of an intracavitary foreign body after surgical procedures, usually textile in origin (Chagas Neto et al., 2012).

The textile material that is left behind following a surgical procedure is enveloped by a granulomatous inflammatory reaction and this response is called gossypiboma (Martins et al., 2009). The body responds to the presence of the textile, which is aforeign object,in two ways: the first is aseptic, while the second exudative. The aseptic response is one that leads to the formation of adhesions, encapsulation, and formation of a granuloma-type foreign body. In this case, the patient may remain asymptomatic for years (Silva e Souza, 2013). The exudative response leads to abscess formation and development of fistulas with the organs of the affected cavity or with the abdominal wall. Gossypiboma can present with numerous differential diagnoses, such as abscess, tumor, metastasis, or hematoma (Ribalta et al., 2004). In humans, the diagnosis can be difficult, since the symptoms are nonspecific and may only arise years after the surgical procedure (Silva e Souza, 2013). In this context, we aimed to report the clinical, surgical, and pathological findings of a case of gossypiboma in dogs.

\section{CASE REPORT}

A dog, German shepherd breed, female, weighing $23 \mathrm{~kg}$ and 9 years old, was brought to the Small Animal Surgical Clinic of the Governador Laudo Natel Veterinary Hospital at FCAV-UNESP, Jaboticabal/SP, presenting with increasedintraabdominalvolume with mesogastric and progressive weight loss, associated with cachexia and regurgitation over the last 6 months. The patient had undergone elective ovariohysterectomy 5 years ago. A blood test revealed leukocytosis without left shift and discrete hypoalbuminemia.

The patient was referred to the imaging diagnostic service in order to clarify the origin of the intra-abdominal volume increase. Ultrasonography revealed a discrete amount of free fluid individualizing the hepatic lobes and the presence of a structure in the mesogastric region, making it difficult to evaluate the spleen, right kidney, and pancreas, displacing segments of intestinal loops due to its anatomic topography, and with increased echogenicity of the adjacent mesentery in the visible portions. The formation had a well-defined, hyperechogenic contour, with a capsule measuring approximately $1.11 \mathrm{~cm}$ thick, composed of mixed echogenicity, predominantly hyperechogenic content with hypoechogenic areas, and the presence of small, irregular, and hyperechogenic structures forming a posterior acoustic shadow and a moderate amount of anechoic content (Figure 1).

Thoracic radiographic examination showed the esophagus was markedly distended by heterogeneous content of greater radiopacity (food), which displaced ventrally the thoracic trachea, cranial mediastinal structures, and cardiac silhouette, compatible with megaesophagus (Figure 2).

In the radiographic examination of the abdominal region, the homogeneous aspect of the abdomen with slightly increased radiopacity was visualized, with water density, irregular tapering structures of greater radiopacity in the ventral mesogastric region, and dorsolateral displacement of the descending colon (Figure 3).

Due to the limitations of the imaging complementary examinations, it was not possible to determine the origin of the formation in the mesogastric region. Presented with these findings, we opted for exploratory laparotomy. 


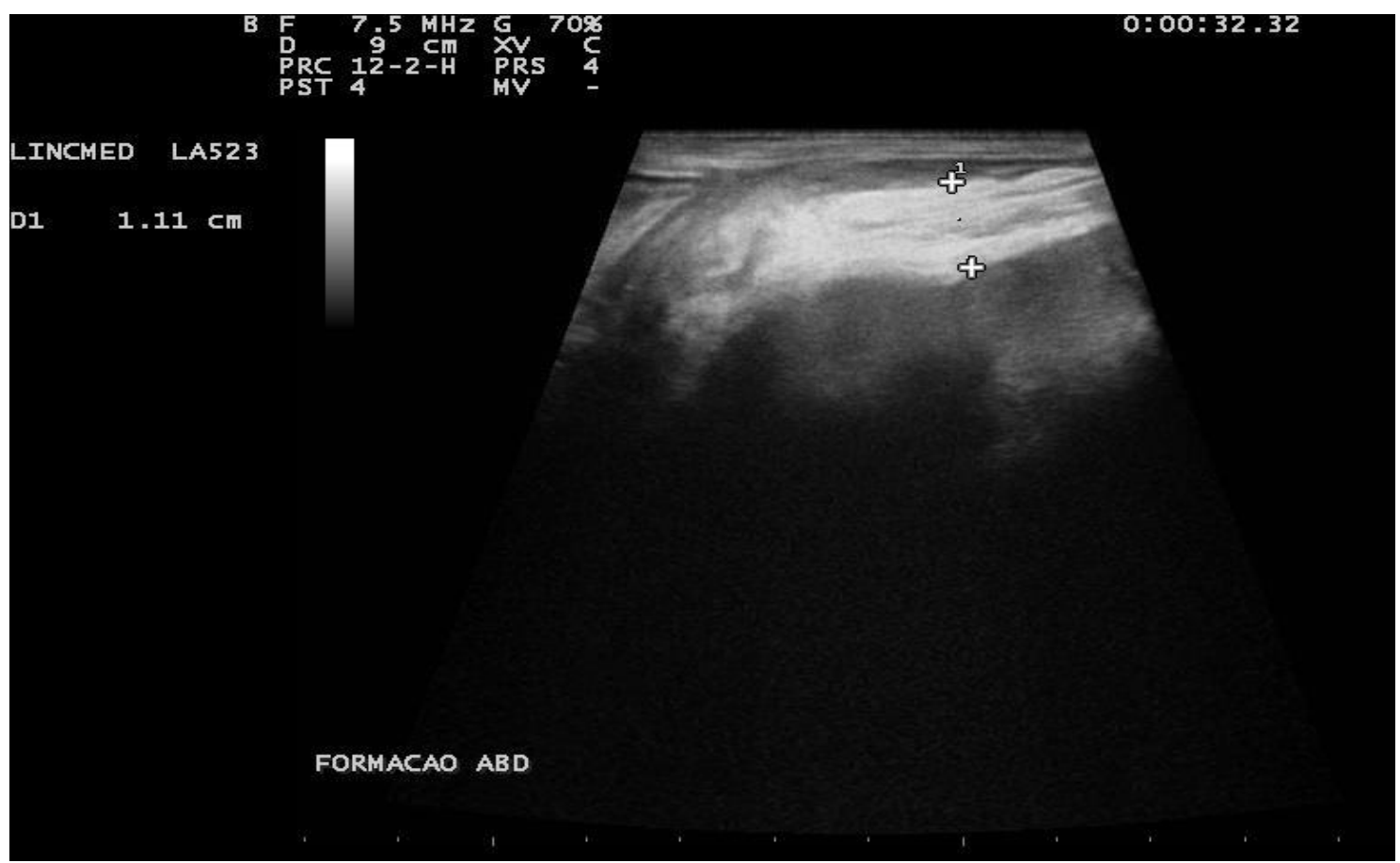

Figure 1. Ultrasonographic aspect of intra-abdominal gossypiboma in a dog. Note gossypiboma capsule thickening (+). Jaboticabal, 2015.

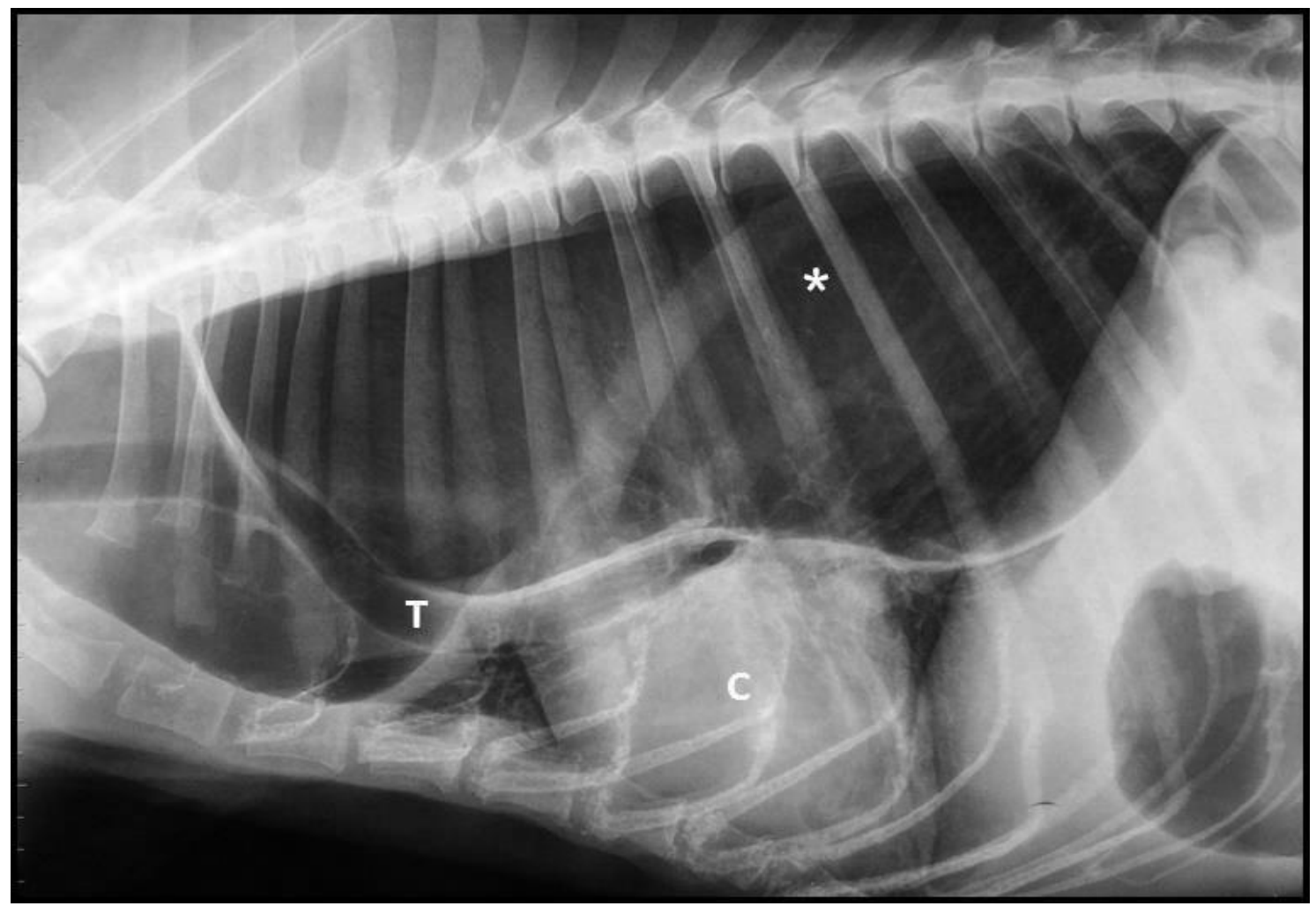

Figure 2. Radiographic aspect of megaesophagus in a dog. Note severe dilatation of the thoracic esophagus $(*)$, causing displacement of the trachea (T) and heart (C). Jaboticabal, 2015. 


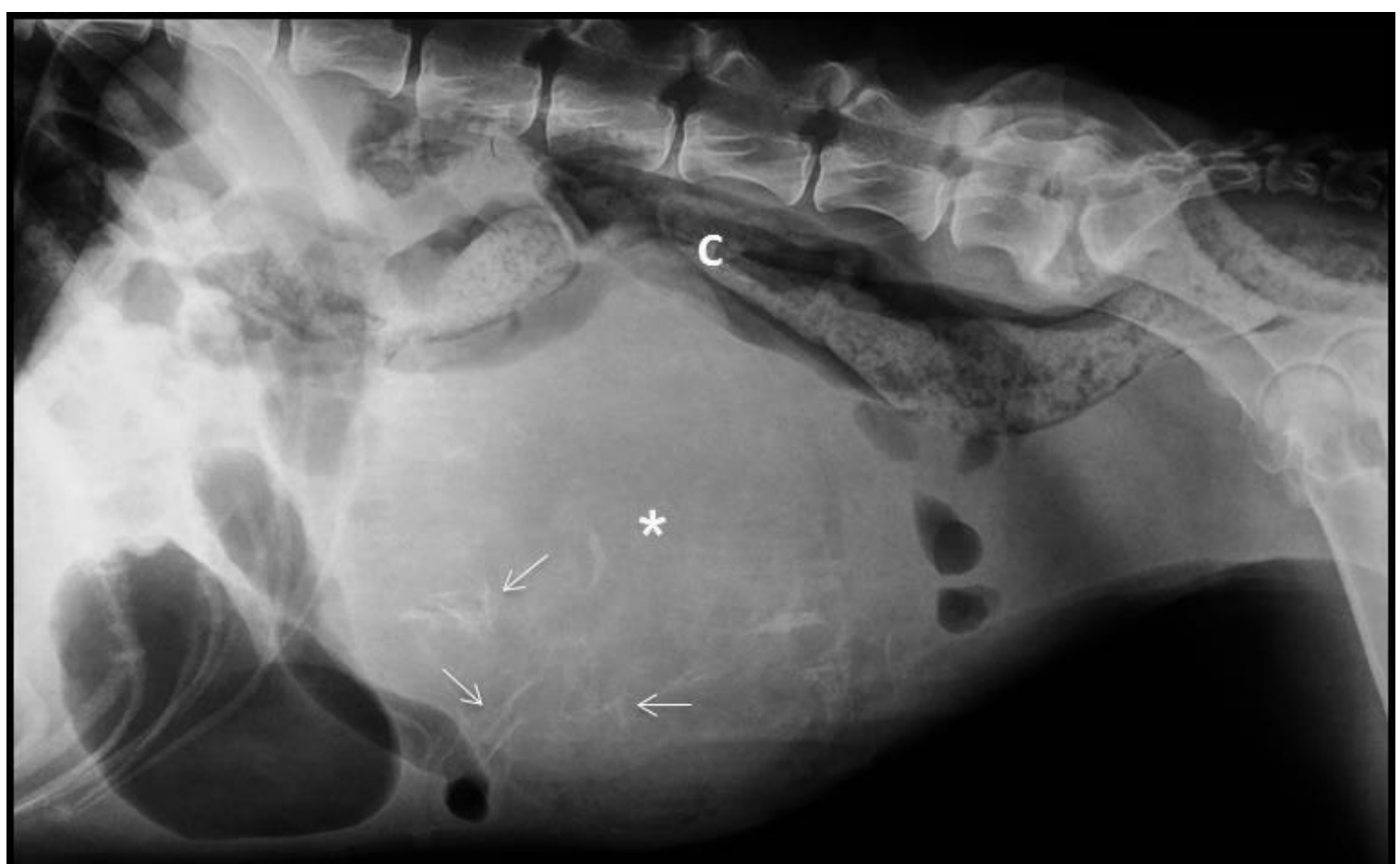

Figure 3. Radiographic aspect of intra-abdominal gossypiboma in a dog. Latero-lateral abdominal radiography with the presence of a large water-radiodensity structure $(*)$ containing central radiopaque sharp structures (arrows), causing displacement of the colon (C). Jaboticabal, 2015.

The patient was premedicated with morphine $(0.5 \mathrm{mg} / \mathrm{kg} \mathrm{IM})$ and the anesthetic induction made with intravenous application of etomidate $(1 \mathrm{mg} / \mathrm{kg})$ plus midazolam $(0.5 \mathrm{mg} / \mathrm{kg})$. Anesthetic maintenance was obtained with isoflurane $(0.5 \%)$. In addition to general inhalation anesthesia, an epidural block with lidocaine $(4 \mathrm{mg} / \mathrm{kg})$ associated with bupivacaine $(0.5 \mathrm{mg} / \mathrm{kg})$ was also performed. Immediately after induction, the patient had a heart rate (HR) of $90 \mathrm{bpm}, \mathrm{SaO}_{2}$ of $98 \%, \mathrm{EtCO}_{2}$ of $59 \mathrm{mmHg}$, and MAP of $38 \mathrm{mmHg}$. Because the blood pressure could not be maintained, a continuous infusion of noradrenaline $(0.3 \mu \mathrm{g} / \mathrm{kg} / \mathrm{min})$ was instituted, which was maintained throughout the surgery. At the same time, assisted ventilation was performed. Other drugs used during the surgical procedure were: cefazolin $(30 \mathrm{mg} / \mathrm{kg})$, metronidazole $(30 \mathrm{mg} / \mathrm{kg})$, and enrofloxacin $(5 \mathrm{mg} / \mathrm{kg})$ at the beginning of anesthesia, and acetylcysteine $(75 \mathrm{mg} / \mathrm{kg})$ prior to removal of the mass in the abdomen, all intravenously. Extubation occurred 4 hours after the onset of anesthesia.
During surgery, the presence of a mass adherent to the spleen and to the root of the mesentery was observed (Figure 4). After surgical excision, it was decidedthat a gastronomy be performed, using a silicone gastric tube to ensure the nutritional intake of the patient. Postoperative treatment consisted of systemic antimicrobial therapy, using cephalexin $30 \mathrm{mg} / \mathrm{kg} / \mathrm{BID}$, metronidazole $20 \mathrm{mg} / \mathrm{kg} / \mathrm{BID}$, and enrofloxacin $5 \mathrm{mg} / \mathrm{kg} / \mathrm{BID}$. Analgesia was provided with tramadol hydrochloride $4 \mathrm{mg} / \mathrm{kg} / \mathrm{TID}$, scopolamine and dipyrone $25 \mathrm{mg} / \mathrm{kg} / \mathrm{TID}$, and gastric mucosal protectors omeprazole $1 \mathrm{mg} / \mathrm{kg} / \mathrm{TID}$ and sucralfate $30 \mathrm{mg} / \mathrm{kg} / \mathrm{TID}$.

The mass was sent to the Department of Veterinary Pathology and on macroscopic examination, measured $22 \times 19 \times 4 \mathrm{~cm}$, with a smooth, firm, and purple-gray outer surface. When cut, an abundant cloudy rosy fluid was drained with a putrid odor associated with a marked amount of yellow-brown textile structures (surgical dressings) in the center of the mass (Figure 5). 


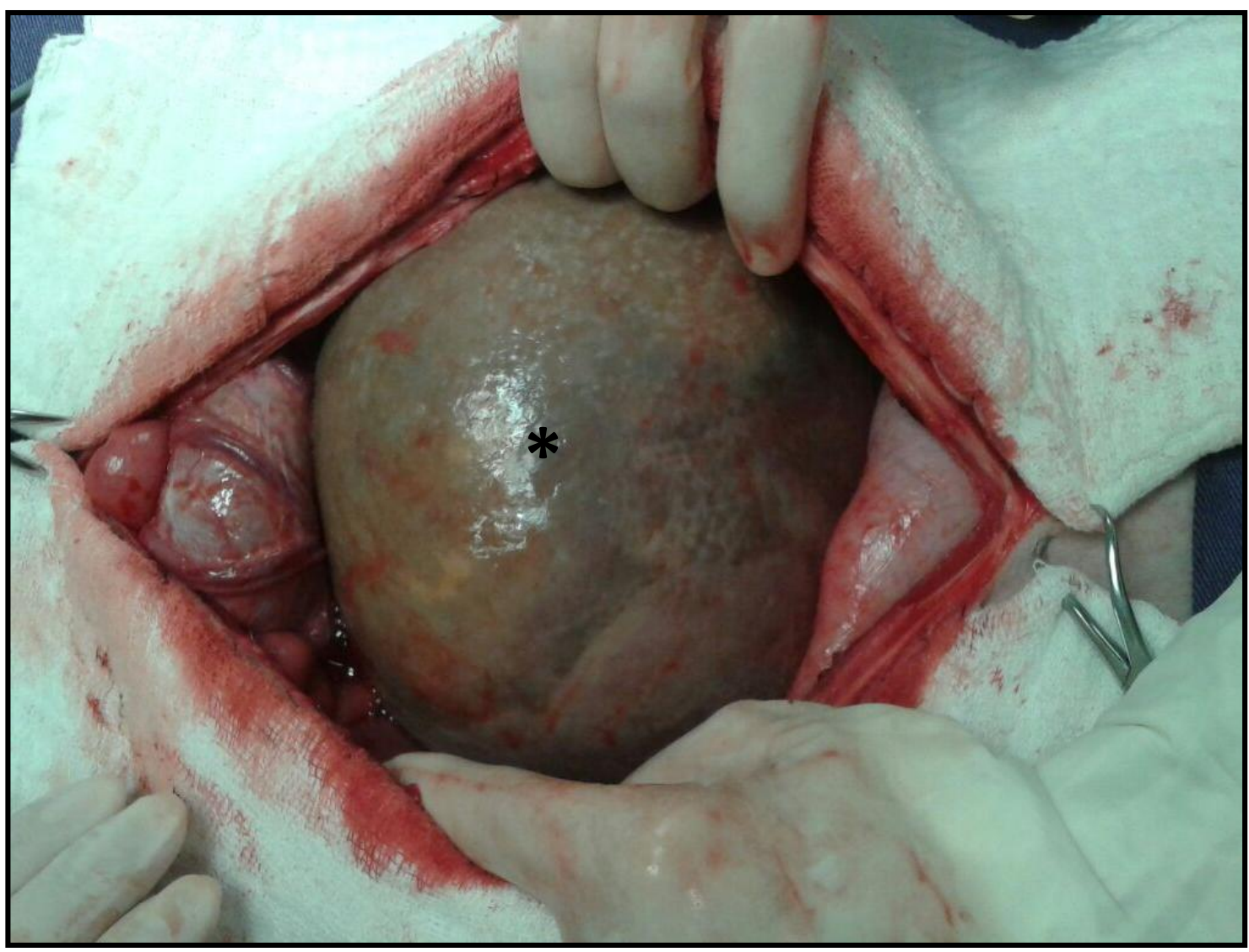

Figure 4. Intra-abdominal mass observed during an exploratory laparotomy in a dog. In situ appearance of the gossypiboma during the surgical procedure. Jaboticabal, 2015.

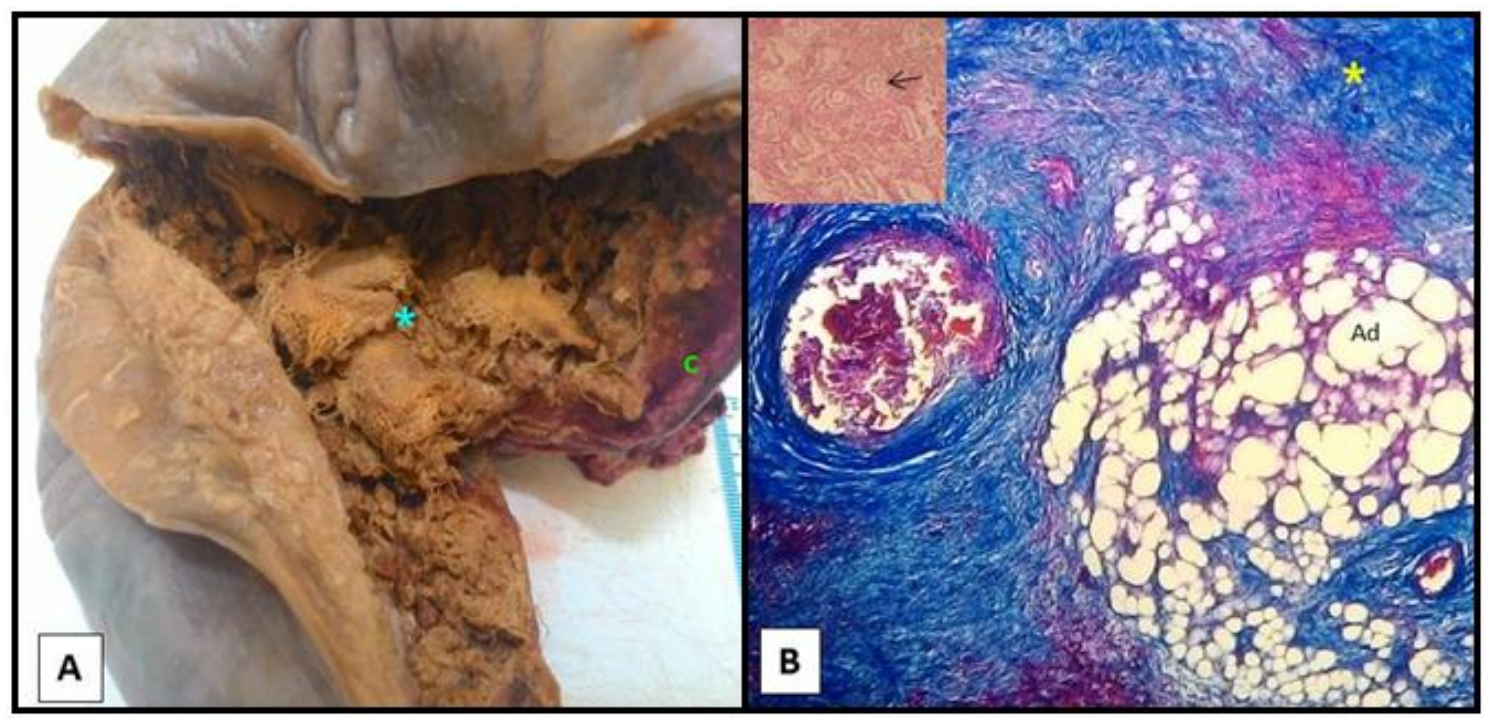

Figure 5. Anatomopathological findings of a canine gossypiboma. A) Aspect of the gossypiboma immediately after surgical excision. Observe the fibrous capsule (C) and at the center the textile residues (*). B) Photomicrography of a gossypiboma with severe desmoplasia (*) and surrounding adipocytes (Ad). (Masson Trichrome / obj. 10x). Detail of textile material amphophilic aspects (arrow) surrounded by necrotic debris acidophilus (hematoxylin and eosin / Obj. 40×.). Jaboticabal, 2015. 
Much of this material was removed and but some adhered to the reddish fibrous capsule. The cytological aspect of the rosy liquid was amorphous and without cellularity, only with cellular debris. Fixation of the material was performed with $10 \%$ formalin solution, buffered with phosphate ( $\mathrm{pH}$ 7.4). For histopathological evaluation, it was stained with hematoxylin and eosin and Masson's trichrome, which revealed lush mature granulation tissue surrounding adipose tissue foci, severe hemorrhage, central areas with amorphous necrotic material, and eosinophilic associated with amphophilic fragments of textile material (Figure 5), as well as a marked presence of hematoidin pigment and discrete foci of dystrophic calcification. No inflammatory process associated with the lesion was observed.

On the second postoperative day, the patient returned to the hospital with tachypnea, abdominal tenderness, and greenish secretion around the gastric tube, and died after 12 hours, despite presenting with a hematological result within the reference values.

\section{DISCUSSION}

The literature consulted for the present study was predominantly from human medicine, due to the lack of work in veterinary medicine, which made it difficult to directly compare the findings with similar studies. Previous studies have pointed out that foreign bodies are often found after cavitary surgeries in humans, diverging from the work of Marques et al. (2014) who reported otherwise.

Among the ultrasound classification of gossypiboma reported by Chagas Neto et al. (2012), the ultrasonographic findings of the present case revealed a non-specific aspect of a complex mass. Following what has been reported by Singh et al. (2004), the treatment indicated in this case was laparotomy for surgical excision.

According to Peace and Riggs (2014), the mass promoted compression of adjacent organs and was adherent to the abdominal cavity.In this case report, the patient presented with megaesophagus and her nutritional intake was further impaired by the partial obstruction that the mass caused on the intestinal loops, consistent with the reports of these authors.
Before death, the patient presented with high pain sensitivity to abdominal palpation in the postoperative period, like that described by Peace and Riggs (2014). The macroscopic appearance, as well as histopathological findings were also similar to those described by these authors. As the owner did not authorize the procedure, the animal did not undergo necroscopic examination, which made it impossible to elucidate the systemic alterations and exact cause of death.

However, the contribution of the megaesophagus to the worsening of the clinical condition of the animal should not be ruled out, since this alteration was severe and may have caused weakness due to frequent regurgitation. Unfortunately, it was not possible to evaluate if the megaesophagus was a pathological process idiopathic or secondary to the gossypiboma. Some authors report a genetic predisposition to this condition among some breeds, including the German shepherd. They also describe numerous causes of secondary megaesophagus, including esophageal motor or gastroesophageal sphincter injuries, which could cause dilation of the esophageal wall, including some tumors (Tanaka et al., 2010). Perhaps the gossypiboma caused significant compression of the abdominal viscera, to the point of compromising the function of the gastroesophageal sphincter.

The presence of a surgical compress in the abdominal cavity constitutes a situation of negligence, as described in the Veterinarian's Code of Ethics (Brasil, 2002), which determines the punishment of the offender according to the severity of the infraction. In the present case, there was no complaint by the owner, as was the case of Marques et al. (2014).

There are few studies in veterinary medicine that report cases of gossypiboma and its consequences for the animals, presumably due to the medical-legal nature that covers such complications. At the end of any invasive surgical procedure, it is necessary to ensure the non-existence of any surgical material in the patient's abdominal cavity, thereby avoiding exuberant reactions to the foreign body as occurred in the present case.Because of this fact, it is important that veterinarians publish reports with similar findings in order to disseminate knowledge and alert both veterinarians and the 
owners to their rights and duties and the complications that may occur resulting from acts of negligence, incompetence, or recklessness.

\section{CONCLUSION}

It is necessary that the ovariohysterectomy is performed exclusively by properly trained professionals and that castration campaigns are conducted in a manner that allows the quality of the exercise of the veterinarian's work. Likewise, it is imperative that surgeons as well as their assistants make sure that none of their procedures put the patient's life at risk.

\section{REFERENCES}

BRASIL. Conselho Federal de Medicina Veterinária. Código de ética do médico veterinário. Disponível em: <www.crmvsp.gov.br//site/cod_etic_med_vete.p hp>. Acessado em: 01 set 2015.

CHAGAS NETO, F.A.; AGNOLLITTO, P.M.; MAUAD, F.M. et al.Avaliação por imagem dos gossipibomas abdominais. Radiol. Bras., v.45, p.53-58, 2012.

EKO, S.T. Indenização por erro do clínico médico veterinário. Rev. Clin. Vet., v.95, p.106, 2011.

MALACARNE, G. Prontuário clínico do médico veterinário. 2009. Disponível em: <www.crmvpr.org.br/?p=imprensa/artigo_ detalhes\&id=56>. Acessado em: 7 set 2015.

MARQUES, L.M.; ALBERTO CARLOS, R.S.; SILVA, E.B. et al.Imperícia e negligência em ováriosalpingohisterectomia de uma cadela relato de caso.Rev. Bras. Med. Vet., v.36, p.425429, 2014.
MARTINS, M.C.B.; AMARAL, R.P.G.; ANDRADE, C.S. et al. Características de imagem na ressonância magnética de gossipiboma intracraniano: relato de caso e revisão da literatura. Radiol. Bras., v.42, p.407409, 2009.

PEACE, A.C.; RIGGS, M. "Gossypibomainduced abdominal fibrosarcoma in a german shepherd." Vet. Med., 2014. Available in: <http://www.highbeam.com>. Accessed in: 24 Sep. 2015.

RIBALTA, T.; MCCUTCHEON, I.E.; NETO, A.G. et al.Textiloma (gossypiboma) mimicking recurrent intracranial tumor. Arch. Pathol. Lab. Med., v.128, p.749-758, 2004.

SANTOS, F.C.; CORREIA, T.P.; RAHAL, S.C. et al. Complicações da esterilização cirúrgica de fêmeas caninas e felinas. Revisão de literatura. Vet. Zootec., v.16, p.8-18, 2009.

SILVA, S.M.; SOUSA, J.B. Gossipiboma após operação abdominal é situação clínica desafiadora e sério problema médico legal. Arq. Bras. Cir. Dig., v.2, p.140-143, 2013.

SINGH, R.; MATHUR, R.K.; PATIDAR, S.; TAPKIRE, R. Gossypiboma: its laparoscopic diagnosis and removal. Surg. Laparosc. Endosc .Percutan Tech., v.14, p.304-305, 2004.

TANAKA, N.M.; HOOGEVONINK, N.; TUCHOLSKI, A.P. et al.Megaesôfago em cães. Rev. Acad. Ciênc. Agrár. Ambient., v.8, p.271279, 2010. 